\title{
$( \pm)$-Zanthonitidine A, a Pair of Enantiomeric Furoquinoline Alkaloids from Zanthoxylum nitidum with Antibacterial Activity
}

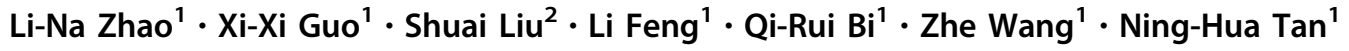

Received: 4 May 2018 / Accepted: 18 May 2018 / Published online: 31 May 2018

(C) The Author(s) 2018

\begin{abstract}
A pair of new enantiomeric furoquinoline alkaloids, $( \pm)$-zanthonitidine A (1), together with nine known ones (2-10) were isolated from the radix of Zanthoxylum nitidum. Their chemical structures were elucidated based on the extensive spectroscopic analysis. The racemic mixture of $\mathbf{1}$ was separated by chiral column chromatography, and the absolute configurations of (+)-1 and (-)-1 were determined by the comparison of experimental and calculated electronic circular dichroism spectra. Antibacterial activities of compounds 1-9 were evaluated, and compounds (+)-1, (-)-1, 3, 7 and 8 showed antibacterial activities against Bacillus subtilis, Enterococcus faecalis or Staphylococcus aureus.
\end{abstract}

Li-Na Zhao and Xi-Xi Guo have contributed equally to this work.

Electronic supplementary material The online version of this article (https://doi.org/10.1007/s13659-018-0169-7) contains supplementary material, which is available to authorized users.

Zhe Wang

wangzhe@cpu.edu.cn

$\bowtie$ Ning-Hua Tan

nhtan@cpu.edu.cn

1 Department of TCMs Pharmaceuticals, School of Traditional Chinese Pharmacy, China Pharmaceutical University, Nanjing 211198, China

2 Faculty of Life Science and Food Engineering, Huaiyin Institute of Technology, Huaian 223001, China 


\section{Graphical Abstract}

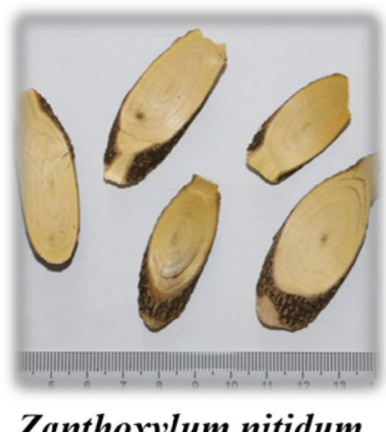

Zanthoxylum nitidum<smiles>COc1cc([C@H](O)[C@@]2(C)COc3ccc4c(OC)c5ccoc5nc4c3OC2)cc(OC)c1O</smiles>

$(+)-1$<smiles>COc1cc(C(O)[C@H]2COc3c(ccc4c(OC)c5ccoc5nc34)O2)cc(OC)c1O</smiles>

$(-)-1$

Antimicrobial activities of (+)-1 and (-)-1. (MIC, $\mu \mathrm{g} / \mathrm{mL})$

\begin{tabular}{ccc}
\hline Compounds & E. faecalis & S. aureus \\
\hline$(+)-1$ & 21.97 & 21.97 \\
$(-)-1$ & 12.54 & 25.09 \\
\hline
\end{tabular}

Keywords Zanthoxylum nitidum · Furoquinoline alkaloids · Zanthonitidine A · Antibacterial activity

\section{Introduction}

The genus Zanthoxylum Linn of the Rutaceae family comprises of about 250 species in the world, mainly distributed in Asian, America, Africa, tropical and subtropical regions in Oceania. There are 39 species and 14 varietas in China [1], and the largest part occurs in south of the Yangtze River and south western provinces [2]. Zanthoxylum nitidum (Roxb.) DC. (Rutaceae) is a morphologically variable species with hooked prickly branchlets plant of the Zanthoxylum genus [3]. The radix of Z. nitidum was recorded as a traditional Chinese medicine, named "liangmianzhen" in Chinese Pharmacopeia (Version 2015), and has been widely used for the treatment of toothache, neuralgia, stomachache, sore throat, rheumatoid arthritis, turgescence and venomous snake bite [4]. It was main raw material of Chinese herbal toothpaste called "liangmianzhen", and it is also used for some preparations, such as Jinji Tablet, Dieda Wanhua Oil. Several types of alkaloids including quinolines, isoquinolines, quinolones and benzophenanthridines, have previously been isolated from Z. nitidum $[3,5,6]$, and some other kinds of compounds including coumarins and lignans, were also reported in this plant [5, 7]. Among them, alkaloids, especially benzophenanthridines, are considered as the main bioactive constituents, which show various pharmacological activity, including inhibiting DNA topoisomerase I [8], anti-inflammatory [6], anti-nociceptive [9], inhibiting the growth and inducing the pro-apoptosis [10]. With the purpose to discover more pharmacological alkaloids, we performed the phytochemical investigation on the radix of $Z$. nitidum. As a result, a pair of new enantiomeric furoquinoline alkaloids, ( \pm )-zanthonitidine A (1) (Fig. 1), together with nine known alkaloids (2-10) (Fig. S1) were obtained. Herein, we report their isolation, structural elucidation, and antibacterial activity.

\section{Results and Discussion}

Zanthonitidine A (1) was obtained as a yellow powder. Its molecular formula was determined by HRESIMS $\left([\mathrm{M}+\mathrm{H}]^{+}, 440.13478\right.$, calcd. 440.13399) as $\mathrm{C}_{23} \mathrm{H}_{21} \mathrm{NO}_{8}$, implying fourteen degrees of unsaturation. The IR spectrum showed the absorptions at 3425 and $1624 \mathrm{~cm}^{-1}$, indicating the existence of hydroxyl and phenyl groups. The ${ }^{1} \mathrm{H}$ NMR spectrum (Table 1) showed two pairs of $\mathrm{AB}$ doublets at $\delta_{\mathrm{H}} 7.79(1 \mathrm{H}, \mathrm{d}, J=9.2 \mathrm{~Hz}), 7.56(1 \mathrm{H}, \mathrm{d}$, $J=2.3 \mathrm{~Hz}), 7.14(1 \mathrm{H}, \mathrm{d}, J=9.2 \mathrm{~Hz}), 7.06(1 \mathrm{H}, \mathrm{d}$, $J=2.3 \mathrm{~Hz})$; two aromatic protons at $\delta_{\mathrm{H}} 6.68(2 \mathrm{H}, \mathrm{s})$; one methylene group at $\delta_{\mathrm{H}} 3.86(1 \mathrm{H}, \mathrm{dd}, J=12.6,1.5 \mathrm{~Hz})$, $3.71(1 \mathrm{H}, \mathrm{dd}, J=12.6,5.3 \mathrm{~Hz})$; two methyne groups at $4.95(1 \mathrm{H}, \mathrm{d}, J=8.1 \mathrm{~Hz}), 4.22(1 \mathrm{H}, \mathrm{m})$; three methoxyl groups at $\delta_{\mathrm{H}} 4.44(3 \mathrm{H}, \mathrm{s}), 3.91(6 \mathrm{H}, \mathrm{s})$. The ${ }^{13} \mathrm{C}$ NMR spectrum displayed 15 aromatic carbons at $\delta_{\mathrm{C}} 163.8(\mathrm{~s})$, 158.2 (s), 147.7 (s), 147.7 (s), 143.8 (s), 137.0 (s), 135.8 (s), 135.8 (s), 127.2 (s), 116.5 (d), 115.1 (d), 114.6 (s), 104.6 (d), 104.6 (d), 102.8 (s); two olefinic carbons at $\delta_{\mathrm{C}}$ 


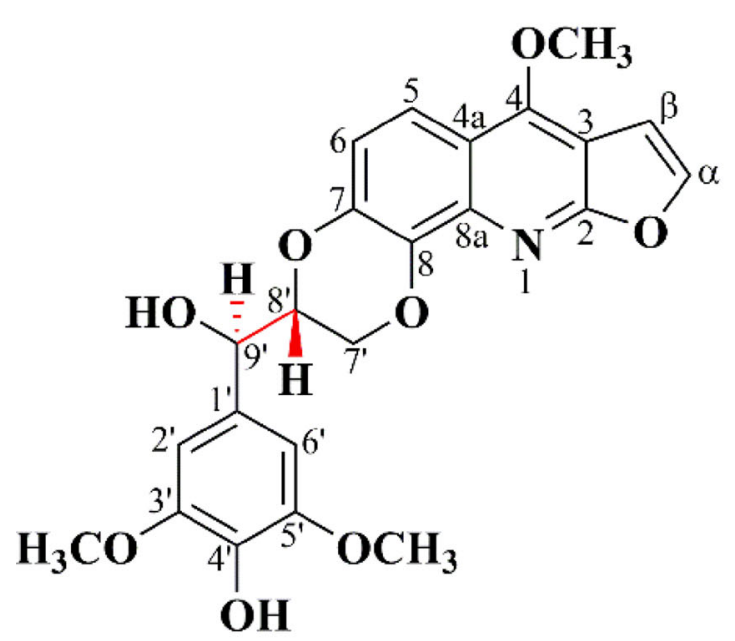

$(+)-1$

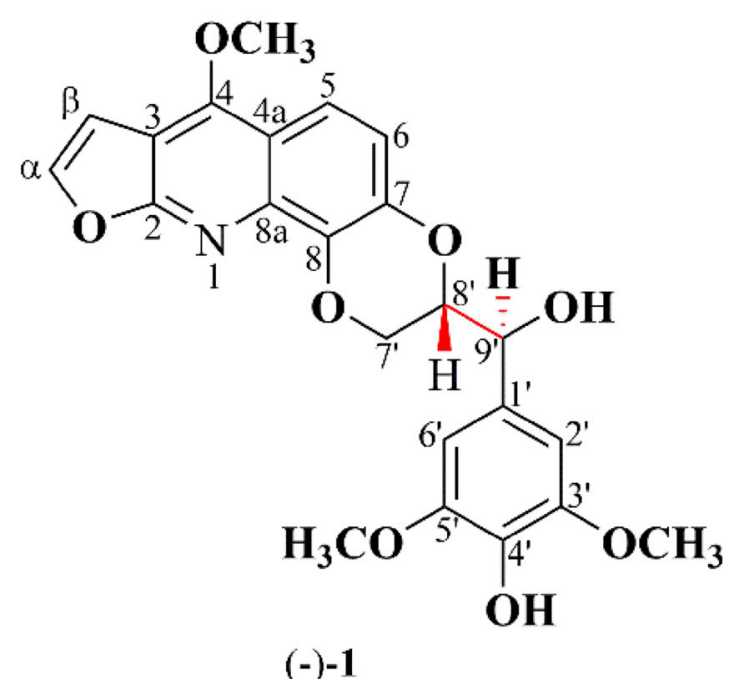

$(-)-1$

Fig. 1 Chemical structures of $( \pm)$-zanthonitidine A (1)

Table $1{ }^{1} \mathrm{H}(600 \mathrm{MHz}, \delta$ in ppm, $J$ in $\mathrm{Hz})$ and ${ }^{13} \mathrm{C}$ NMR $(150 \mathrm{MHz}, \delta$ in ppm) data of zanthonitidine $\mathrm{A}(\mathbf{1})$ in $\mathrm{CDCl}_{3}$

\begin{tabular}{llr}
\hline Position & $\delta_{\mathrm{H}}(\mathrm{m}, J, \mathrm{~Hz})$ & $\delta_{\mathrm{C}}$ \\
\hline 2 & & 163.8 \\
3 & & 102.8 \\
4 & & 158.2 \\
$4 \mathrm{a}$ & & 114.6 \\
5 & $7.79(\mathrm{~d}, 9.2)$ & 115.1 \\
6 & $7.14(\mathrm{~d}, 9.2)$ & 116.5 \\
7 & & 143.8 \\
$8,4^{\prime}$ & & 135.8 \\
$8 \mathrm{a}$ & & 137.0 \\
$1^{\prime}$ & & 127.2 \\
$2^{\prime}, 6^{\prime}$ & & 104.6 \\
$3^{\prime}, 5^{\prime}$ & $6.68(\mathrm{~s})$ & 147.7 \\
$7^{\prime} \mathrm{a}$ & & 61.7 \\
$7^{\prime} \mathrm{b}$ & $3.71(\mathrm{dd}, 12.6,1.5)$ & \\
$8^{\prime}$ & $3.86(\mathrm{dd}, 12.6,5.3)$ & 79.4 \\
$9^{\prime}$ & $4.22(\mathrm{~m})$ & 77.4 \\
$\alpha$ & $4.95(\mathrm{~d}, 8.1)$ & 143.3 \\
$\beta$ & $7.56(\mathrm{~d}, 2.3)$ & 105.2 \\
$4-\mathrm{OCH}_{3}$ & $7.06(\mathrm{~d}, 2.3)$ & 59.5 \\
$3^{\prime}, 5^{\prime}-\mathrm{OCH}_{3}$ & $4.44(\mathrm{~s})$ & 56.7 \\
\hline & $3.91(\mathrm{~s})$ & \\
\hline & & \\
\hline
\end{tabular}

143.3 (d), 105.2 (d); one methylene group at $\delta_{\mathrm{C}} 61.7(\mathrm{t})$; two methyne groups at $\delta_{\mathrm{C}} 79.4$ (d), 77.4 (d); three methoxyl groups at $\delta_{\mathrm{C}} 59.5(\mathrm{q}), 56.7$ (q), 56.7 (q). Based on these data, 1 was presumed to be a furoquinoline containing glycerol and benzene moieties.

The structure was elucidated by detailed interpretation of 2D NMR correlations (Fig. 2). The HMBC correlations from $\delta_{\mathrm{H}} 7.56(\mathrm{H}-\alpha)$ to $\delta_{\mathrm{C}} 163.8(\mathrm{C}-2)$ and $\delta_{\mathrm{C}} 102.8(\mathrm{C}-3)$;

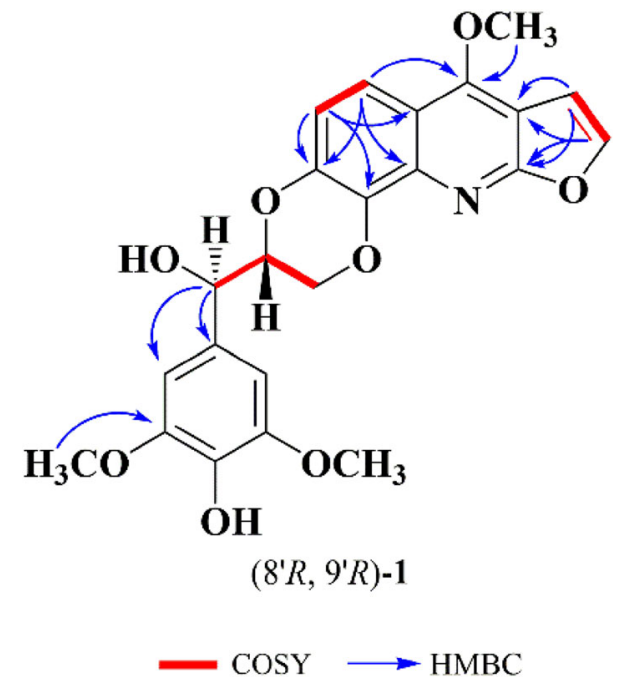

Fig. 2 Key 2D NMR correlations of ( \pm )-zanthonitidine A (1)

from $\delta_{\mathrm{H}} 7.06(\mathrm{H}-\beta)$ to $\delta_{\mathrm{C}} 163.8(\mathrm{C}-2)$ and $\delta_{\mathrm{C}} 102.8(\mathrm{C}-3)$; from $\delta_{\mathrm{H}} 7.79(\mathrm{H}-5)$ to $\delta_{\mathrm{C}} 158.2(\mathrm{C}-4), 143.8(\mathrm{C}-7)$, and $137.0(\mathrm{C}-8 \mathrm{a})$; from $\delta_{\mathrm{H}} 7.14(\mathrm{H}-6)$ to $\delta_{\mathrm{C}} 143.8(\mathrm{C}-7), 135.8$ $(\mathrm{C}-8)$, and $114.6(\mathrm{C}-4 \mathrm{a})$; from $\delta_{\mathrm{H}} 4.44\left(4-\mathrm{OCH}_{3}\right)$ to $\delta_{\mathrm{C}}$ 158.2 (C-4); together with the ${ }^{1} \mathrm{H}-{ }^{1} \mathrm{H}$ COSY correlations of $\mathrm{H}-\alpha / \mathrm{H}-\beta$ and $\mathrm{H}-5 / \mathrm{H}-6$ gave a furoquinoline moiety. The $\mathrm{HMBC}$ correlations from $\delta_{\mathrm{H}} 4.95\left(\mathrm{H}-9^{\prime}\right)$ to $\delta_{\mathrm{C}} 127.2\left(\mathrm{C}-1^{\prime}\right)$ and $\delta_{\mathrm{C}} 104.6\left(\mathrm{C}-2^{\prime}\right) ; \delta_{\mathrm{H}} 3.91\left(3^{\prime}-\mathrm{OCH}_{3}\right)$ to $\delta_{\mathrm{C}} 147.7\left(\mathrm{C}-3^{\prime}\right)$; together with the ${ }^{1} \mathrm{H}-{ }^{1} \mathrm{H}$ COSY correlations of $\mathrm{H}-7^{\prime} / \mathrm{H}-8^{\prime}$ and $\mathrm{H}-8^{\prime} / \mathrm{H}-9^{\prime}$ suggested a glycerol segment at $\mathrm{C}-1^{\prime}$ position of benzene moiety. In consideration of the degrees of unsaturation and the chemical shift of $\delta_{\mathrm{C}} 143.8(\mathrm{C}-7)$ and $\delta_{\mathrm{C}} 135.8(\mathrm{C}-8)$, the $\mathrm{C}-\mathrm{O}$ bonds should exist in $\mathrm{C}-7 / \mathrm{C}-8^{\prime}$ and $\mathrm{C}-8 / \mathrm{C}-7^{\prime}$, and formed a 1,4-dioxane moiety. Thus, the planar structure of $\mathbf{1}$ was established. There is no obvious 
Column: Chiralpak ID column $(4.6 \mathrm{~mm} \times 250 \mathrm{~mm} ; 5 \mu \mathrm{m})$

Mobile Phase: EtOH-TFA (100 : 0.1 ); $0.5 \mathrm{~mL} / \mathrm{min}$

Absorption wavelength: 254 nm

2.00

1.60

1.40

1.20

0.80

0.40

0.00

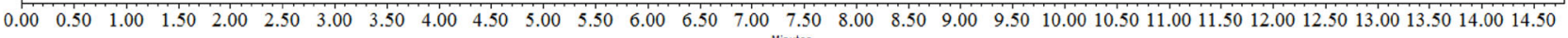

Fig. 3 Chiral analysis of zanthonitidine A (1)<smiles>COc1cc(C(O)[C@H]2COc3c(ccc4c(OC)c5ccoc5nc34)O2)cc(OC)c1O</smiles><smiles>COc1cc([C@H](O)[C@H]2COc3c(ccc4c(OC)c5ccoc5nc34)O2)cc(OC)c1O</smiles>

b

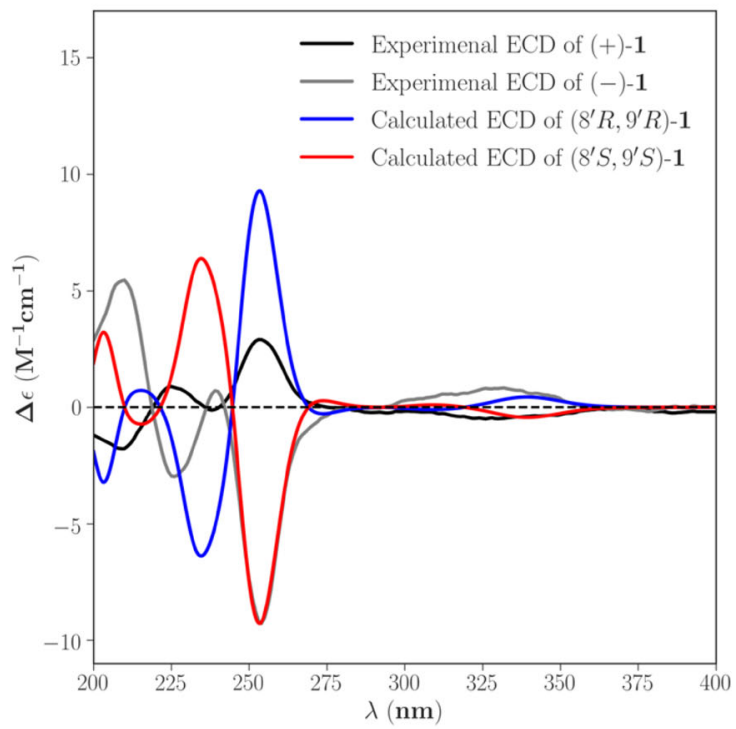

Fig. 4 a Two possible stereochemical structures of $\mathbf{1}$; b experimental ECD spectra of $(+)-\mathbf{1} /(-)-\mathbf{1}$ and calculated ECD spectra of $\left(8^{\prime} R, 9^{\prime} R\right) /$ $\left(8^{\prime} S, 9^{\prime} S\right)$ of 1

absorption of electronic circular dichroism, and the coupling constant between the $\mathrm{H}-8^{\prime}$ and $\mathrm{H}-9^{\prime}$ was $8.1 \mathrm{~Hz}$, which indicated that $\mathbf{1}$ was proposed to be a racemate mixture. Further Chiralpak ID column chromatography was performed, and obtained the enantiomers, (+)-1 and
(-)-1 (Fig. 3). The absolute configurations of the enantiomers were then determined by comparing the experimental electronic circular dichroism (ECD) to the caculated ECD using the time-dependent density functional theory (TD-DFT) of the Gaussian 09 program package. The ECD spectra for $\left(8^{\prime} R, 9^{\prime} R\right)-\mathbf{1}$ and $\left(8^{\prime} S, 9^{\prime} S\right)-1$ were calculated at the same theory level. The experimental ECD spectra of (+)-1 and (-)-1 resembled the calculated spectra of $\left(8^{\prime} R, 9^{\prime} R\right)-1$ and $\left(8^{\prime} S, 9^{\prime} S\right)-1$, respectively (Fig. 4). Accordingly, the absolute configurations of $(+)-\mathbf{1}$ and $(-)$ $\mathbf{1}$ were then determined as $\left(8^{\prime} R, 9^{\prime} R\right)-\mathbf{1}$ and $\left(8^{\prime} S, 9^{\prime} S\right)-\mathbf{1}$.

The known compounds were identified as 8-methoxy- $N$ methylflindersine (2, zanthobungeanine) [11], 4-methoxyfuro[2,3-b]quinoline-8-ol (3, robustine) [12], 4-methoxyfuro[2,3-b]-quinoline (4, dictamnine) [13], 4,8-dimethoxy2-quinolone (5, edulitine) [14], 4,7,8-trimethoxyfuro[2,3b]quinoline (6, skimmianine) [15], 4-methoxy- $N$-methyl-2quinolone (7) [16], trans-(-)-9,10-dihydroxy-9,10-dihydrozanthobungeanine (8, zanthodioline) [17], 4,8dimethoxyfuro[2,3-b]quinoline (9, $\gamma$-fagarine) [18] and 4-methoxyfuro[2,3-b]quinoline-8- $O$ - $\beta$-D-glucopyranoside (10) [19] by comparing their spectroscopic data with those reported in the literatures.

The antimicrobial activities of compounds 1-9 was tested on the gram-positive strains Bacillus subtilis, Enterococcus faecalis, and Staphylococcus aureus (Table 2); penicillin was used as the positive control. Both compounds (+)-1 and (-)-1 showed moderate inhibitory activities against Enterococcus faecalis and Staphylococcus aureus with MIC values of $21.97,21.97 \mu \mathrm{g} / \mathrm{mL}$ and 12.54, 25.09 $\mu \mathrm{g} / \mathrm{mL}$, respectively. Compounds $\mathbf{3}, \mathbf{7}$ and $\mathbf{8}$ also showed inhibitory activities against Enterococcus faecalis.

In summary, the phytochemical investigation of the radix of Zanthoxylum nitidum in this study led to the identification of ten alkaloids (1-10) including a pair of 
Table 2 Antibacterial activity of compounds 1-9 (MIC, $\mu \mathrm{g}$ / $\mathrm{mL}$ )

\begin{tabular}{|c|c|c|c|}
\hline Compounds & Bacillus subtilis & Enterococcus faecalis & Staphylococcus aureus \\
\hline$(+)-1$ & $-{ }^{\mathrm{a}}$ & 21.97 & 21.97 \\
\hline$(-)-1$ & - & 12.54 & 25.09 \\
\hline 2 & - & - & - \\
\hline 3 & - & 5.37 & - \\
\hline 4 & - & - & - \\
\hline 5 & - & - & - \\
\hline 6 & - & - & - \\
\hline 7 & - & 18.91 & - \\
\hline 8 & - & 37.83 & - \\
\hline 9 & - & - & - \\
\hline Penicillin ${ }^{\mathrm{b}}$ & 5.92 & $<2.96$ & $<2.96$ \\
\hline
\end{tabular}

${ }^{\mathrm{a}}$ Inactive (MIC $>50 \mu \mathrm{g} / \mathrm{mL}$ )

${ }^{\mathrm{b}}$ Penicillin: positive control new enantiomeric furoquinoline alkaloids, $( \pm)$-zanthonitidine A (1), and nine known ones. Biological assay for the antibacterial activities of 1-9 was performed, and the results showed that $(+)-\mathbf{1},(-)-\mathbf{1}, \mathbf{3}, \mathbf{7}$ and $\mathbf{8}$ possessed antibacterial activities.

\section{Experimental}

\subsection{General Experimental Procedures}

Optical rotations were measured with a Horiba SEPA-300 polarimeter. UV spectra were obtained using a Shimadzu UV-2401A spectrophotometer. CD spectra were tested using Chirascan Circular Dichroism spectrometer. A Tenor 27 spectrophotometer was used for scanning IR spectroscopy with $\mathrm{KBr}$ pellets. MS data were measured on Agilent G6230 TOF Mass spectrometer. 1D-NMR and 2DNMR spectra were measured on a Bruker AM-400, DRX500 or AVANCE III-600 at $298 \mathrm{~K}$. Chemical shifts $(\delta)$ were expressed in parts per million ( $\mathrm{ppm}$ ) with reference to the solvent signals. Semi-preparative HPLC was performed on Waters HPLC system (1525 pump with 2998 photodiode array detector and 2707 autosampler) coupled with Zorbax Eclipse-C18 $(9.4 \mathrm{~mm} \times 250 \mathrm{~mm} ; 5 \mu \mathrm{m})$ for purification or DAICEL Chiralpak ID column $(4.6 \mathrm{~mm} \times$ $250 \mathrm{~mm} ; 5 \mu \mathrm{m}$ ) for chiral analysis. Column chromatography was performed on silica gel (100-200 mesh and 200-300 mesh, Qingdao Yu-Ming-Yuan Chemical Co. Ltd., Qingdao, China), Sephadex LH-20 (Pharmacia Fine Chemical Co., Uppsala, Sweden) or Lichroprep RP-18 gel (40-63 $\mu \mathrm{m}$, Merck, Darmstadt, Germany). Thin layer chromatography (TLC) was performed on silica gel GF254 on glass plates (Qingdao Yu-Ming-Yuan Chemical Co. Ltd.) with detection by visualization with a UV lamp at 254 and $365 \mathrm{~nm}$, and spots were visualized under ultra-violet light and 5\% sulfuric acid-ethanol reagent.

\subsection{Plant Material}

The radix of Zanthoxylum nitidum (Roxb.) DC. (Rutaceae) was purchased from Bozhou Herbal Medicine Market (Anhui, China) in December 2016 and authenticated by Prof. Min-Jian Qin of China Pharmaceutical University. A voucher specimen was deposited in the Herbarium of China Pharmaceutical University.

\subsection{Extraction and Isolation}

The air-dried and milled radix of $Z$. nitidum $(10 \mathrm{~kg})$ was extracted three times with methanol $(3 \times 20 \mathrm{~L})$ under reflux, and the resulting solution was evaporated under reduced pressure to yield the methanol extract $(688.4 \mathrm{~g})$. All amount of the extract was separated by a silica gel column chromatography (CC) (100-200 mesh), eluted with a gradient of $\mathrm{CHCl}_{3}-\mathrm{MeOH}$ (100:0, 95:5, 9:1, 8:2, 7:3, 1:1, $0: 1)$ to yield eleven fractions (Fr. 1-Fr. 11). Fr. 3 (23.7 g) was subjected to silica gel CC (200-300 mesh), eluted with a gradient of petroleum ether-acetone (100:0, 30:1, 10:1, $7: 1,3: 1,1: 1$ ) to yield eight subfractions (Fr. 3-1 to Fr. 3-8). Fr. $3.5(10.0 \mathrm{~g})$ was further purified by RP-18 gel CC $\left(20-100 \% \mathrm{MeOH}-\mathrm{H}_{2} \mathrm{O}\right)$, Sephadex LH-20 CC $\left(\mathrm{CHCl}_{3}-\right.$ $\mathrm{MeOH}, 1: 1)$, and silica gel CC (200-300 mesh) (petroleum ether-chloroform, 1:3) to afford 8-methoxy- $N$ methylflindersine (2) (20.1 mg), 4-methoxyfuro[2,3b]quinoline-8-ol (3) (18.0 mg), and 4,7,8-trimethoxyfuro[2,3-b]quinoline $(6)(22.5 \mathrm{mg})$. Fr. $3.6(5.1 \mathrm{~g})$ was further purified by RP-18 gel CC $\left(20-100 \% \mathrm{MeOH}-\mathrm{H}_{2} \mathrm{O}\right)$ and Zorbax Eclipse $\mathrm{C} 18$ column $\left(41 \%\right.$ acetonitrile- $\left.\mathrm{H}_{2} \mathrm{O}\right)$ to afford 4-methoxy- $N$-methyl-2-quinolone (7) (10.8 mg), 
trans-(-)-9,10-dihydroxy-9,10-dihydrozanthobungeanine (8) $(17.8 \mathrm{mg})$, and 4,8-dimethoxyfuro[2,3-b]quinoline (9) $(17.0 \mathrm{mg})$. Fr. 3.7 (7.2 g) was further separated by RP-18 gel $\mathrm{CC}\left(20-100 \% \mathrm{MeOH}-\mathrm{H}_{2} \mathrm{O}\right)$ to yield five subfractions (Fr. 3-7-1 to Fr. 3-7-5). 4,8-dimethoxy-2-quinolone (5) (15.6 mg) was crystallized out of Fr. 3-7-2. Fr. 3-7-3 was subjected to Sephadex LH-20 CC $\left(\mathrm{CHCl}_{3}-\mathrm{MeOH}, 1: 1\right)$ and then purified by Zorbax Eclipse $\mathrm{C} 18$ column (70\% acetonitrile- $\left.\mathrm{H}_{2} \mathrm{O}\right)$ to get zanthonitidine A (1) $(2.7 \mathrm{mg})$ which was further separated by a chiralpak ID column (EtOHTFA, 100:0.1) to yield (+)-1 (0.1 mg) and (-)-1 (0.2 mg). Fr. 6 (25.1 g) was subjected to Sephadex LH-20 CC $\left(\mathrm{CHCl}_{3}-\mathrm{MeOH}, 1: 1\right)$, and then further purified by Zorbax Eclipse $\mathrm{C} 18$ column $\left(60 \%\right.$ acetonitrile- $\left.\mathrm{H}_{2} \mathrm{O}\right)$ to give 4-methoxyfuro[2,3-b]-quinoline (4) (15.1 mg) and 4-methoxyfuro[2,3-b]quinoline-8- $O$ - $\beta$-D-glucopyranoside (10) $(8.3 \mathrm{mg})$.

\subsubsection{Zanthonitidine A (1)}

Yellow powder; UV (MeOH) $\lambda_{\max }(\log \varepsilon) 207.5$ (4.67), 254.5 (4.86), 323.0 (3.80), 407.5 (2.62), 589.5 (2.58) nm; IR (KBr) $v_{\max } 3425,2928,1624,1516,1487,1461,1409$, 1370, 1341, 1298, 1260, 1238, 1156, 1097, 1060, $979 \mathrm{~cm}^{-1} ;{ }^{1} \mathrm{H}(600 \mathrm{MHz})$ and ${ }^{13} \mathrm{C}(150 \mathrm{MHz}) \mathrm{NMR}$ data, see Table 1; ESIMS (positive): $\mathrm{m} / z$ 440.33 $[\mathrm{M}+\mathrm{H}]^{+}$; HRESIMS (positive): $\mathrm{m} / \mathrm{z} 440.13478$ (calcd for $\mathrm{C}_{23} \mathrm{H}_{22} \mathrm{NO}_{8}$, 440.13399).

\subsection{2 (+)-Zanthonitidine A ((+)-1)}

Yellow powder; $[\alpha]_{\mathrm{D}}^{20}+20.0 \quad(c \quad 0.02, \mathrm{MeOH}) ; \mathrm{ECD}$ $(0.23 \mathrm{mM}, \mathrm{MeOH}) \lambda_{\max }(\Delta \varepsilon) 207$ (- 2.5), 213 (- 2.2), 223 (1.2), 239 (- 0.8), 254 (4.0) nm; HRESIMS (positive): $\mathrm{m} / z$ 440.13399 (calcd for $\mathrm{C}_{23} \mathrm{H}_{22} \mathrm{NO}_{8}, 440.13399$ ).

\subsection{3 (-)-Zanthonitidine A ((-)-1)}

Yellow powder; $[\alpha]_{\mathrm{D}}^{20}-93.3 \quad(c \quad 0.01, \mathrm{MeOH}) ; \mathrm{ECD}$ $(0.46 \mathrm{mM}, \mathrm{MeOH}) \lambda_{\max }(\Delta \varepsilon) 203$ (4.3), 210 (7.1), 226 ( -3.6$), 241$ (2.0), 253 (- 11.0) nm; HRESIMS (positive): $\mathrm{m} / \mathrm{z} 440.13338$ (calcd for $\mathrm{C}_{23} \mathrm{H}_{22} \mathrm{NO}_{8}, 440.13399$ ).

\subsection{ECD Calculation}

Conformational analysis was initially performed using Confab at MMFF94 force field for two configurations for $\mathbf{1}$. Room-temperature equilibrium populations were calculated according to Boltzmann distribution law. The conformers with Boltzmann-population of over $1 \%$ were subjected to ECD calculations. The theoretical calculation was carried out using Gaussian 09 [20]. The comformers was initially optimized at PM6 using semiempirical theory method, and then optimized at the B3LYP/6-311G (d, p) in $\mathrm{MeOH}$ using the IEFPCM model. The theoretical calculation of ECD was conducted in $\mathrm{MeOH}$ using Time-dependent Density Functional Theory (TD-DFT) at the same theory level.

\subsection{Antibacterial Assay}

Bacillus subtilis, Enterococcus faecalis, and Staphylococcus aureus were cultured in Luria-Bertani (LB) broth. The broth microdilution assay was applied for the antibacterial activity screening according to CLSI guidelines (CLSI 2015). Bacillus subtilis, E. faecalis, and S. aureus were propagating in the Mueller-Hinton broth $(0.20 \%, w / v$, beef extract; $1.75 \%, w / v$, acid digest of casein; $0.15 \%, w / v$, starch). After incubation with various concentrations of $\mathbf{1}-$ 9 at $37{ }^{\circ} \mathrm{C}$ for $24 \mathrm{~h}$, the 96 -well plates were checked by visual inspection; penicillin was used as the positive control. The MICs were determined as the lowest concentration for no visible growth of bacteria.

Acknowledgements This work was supported by the National Natural Science Foundation of China $(31470428,21702231)$, the National New Drug Innovation Major Project of China (2017ZX09309027), the Program for Jiangsu Province Innovative Research Team, the Fund for Introduction of High-level Talents from China Pharmaceutical University and the Fundamental Research Funds for the Central Universities (2632017PY19).

\section{Compliance with Ethical Standards}

Conflict of interest The authors declare no conflict of interest.

Open Access This article is distributed under the terms of the Creative Commons Attribution 4.0 International License (http://creative commons.org/licenses/by/4.0/), which permits unrestricted use, distribution, and reproduction in any medium, provided you give appropriate credit to the original author(s) and the source, provide a link to the Creative Commons license, and indicate if changes were made.

\section{References}

1. H.M. Yuan, L. Qiu, Z.J. Xie, L. Zou, J. Zheng, Q. Fu, Chin. J. Chin. Mat. Med. 40, 4573-4584 (2015)

2. Y.Y. Liu, W. Cao, Y. Zhang, S.W. Wang, Chin. J. Ethnomed. Ethnopharm. 21, 28-30 (2012)

3. D.Y. Kong, A.I. Gray, T.G. Hartley, P.G. Waterman, Biochem. Syst. Ecol. 24, 87-88 (1996)

4. Editorial Board of 'Zhonghua Bencao', State Administration of Traditional Chinese Medicine of the Peoples Republic of China, Zhonghua Bencao; Shanghai Scientific and Technical Publishing House: Shanghai, 4, 3821 (1999)

5. C.H. Yang, M.J. Cheng, S.J. Lee, C.W. Yang, H.S. Chang, I.S. Chen, Chem. Biodiv. 6, 846-857 (2009)

6. J. Hu, W.D. Zhang, R.H. Liu, C. Zhang, Y.H. Shen, H.L. Li, M.J. Liang, X.K. Xu, Chem. Biodiv. 3, 990-995 (2006) 
7. J.W. Shen, X.F. Zhang, S.L. Peng, L.S. Ding, Nat. Prod. Res. Dev. 17, 33-34 (2005)

8. S.D. Fang, L.K. Wang, S.M. Hecht, J. Org. Chem. 58, 5025-5027 (1993)

9. J. Hu, X.D. Shi, X. Mao, J.G. Chen, L. Zhu, Q.J. Zhao, J. Ethnopharmacol. 150, 828-834 (2013)

10. Z.Q. Fang, Y.Q. Tang, W. Jiao, Z.Q. Xing, Z.X. Guo, W.C. Wang, Z.H. Xu, Z.X. Liu, Food Chem. Toxicol. 66, 210-216 (2014)

11. B.S. Joshi, K.M. Moore, S.W. Pelletier, Phytochem. Anal. 2, 20-25 (1991)

12. A. Chlouchi, C. Girard, F. Tillequin, F. Bévalot, P.G. Waterman, F. Muyard, Biochem. Syst. Ecol. 34, 71-74 (2006)

13. Q.W. Liu, C.H. Tan, S.J. Qu, X. Fan, D.Y. Zhu, Chin. J. Nat. Med. 4, 25-29 (2006)

14. F. Imai, K. Iton, N. Kishibuchi, T. Kinoshita, U. Sankawa, Chem. Pharm. Bull. 37, 119-123 (1989)

15. M. Ratheesh, G. Sindhu, A. Helen, Inflamm. Res. 62, 367-376 (2013)

16. Y.D. Min, H.C. Kwon, M.C. Yang, K.H. Lee, S.U. Choi, K.R. Lee, Arch. Pharm. Res. 30, 58-63 (2007)

17. I.S. Chen, I.W. Tsai, C.M. Teng, J.J. Chen, Y.L. Chang, F.N. Ko, M.C. Lu, Phytochemistry 46, 525-529 (1997)
18. J. Tang, W. Zhu, Z.B. Tu, Chin. Trad. Herb. Drugs 26, 563-565 (1995)

19. J. Liu, C.J. Li, L. Ni, J.Z. Yang, L. Li, C.X. Zang, X.Q. Bao, D. Zhang, D.M. Zhang, RSC Adv. 5, 80553-80560 (2015)

20. M.J. Frisch, G.W. Trucks, H.B. Schlegel, G.E. Scuseria, M.A. Robb, J.R. Cheeseman, G. Scalmani, V. Barone, B. Mennucci, G.A. Petersson, H. Nakatsuji, M. Caricato, X. Li, H.P. Hratchian, A.F. Izmaylov, J. Bloino, G. Zheng, J.L. Sonnenberg, M. Hada, M. Ehara, K. Toyota, R. Fukuda, J. Hasegawa, M. Ishida, T. Nakajima, Y. Honda, O. Kitao, H. Nakai, T. Vreven, J.A. Montgomery Jr., J.E. Peralta, F. Ogliaro, M. Bearpark, J.J. Heyd, E. Brothers, K.N. Kudin, V.N. Staroverov, T. Keith, R. Kobayashi, J. Normand, K. Raghavachari, A. Rendell, J.C. Burant, S.S. Iyengar, J. Tomasi, M. Cossi, N. Rega, J.M. Millam, M. Klene, J.E. Knox, J.B. Cross, V. Bakken, C. Adamo, J. Jaramillo, R. Gomperts, R.E. Stratmann, O. Yazyev, A.J. Austin, R. Cammi, C. Pomelli, J.W. Ochterski, R.L. Martin, K. Morokuma, V.G. Zakrzewski, G.A. Voth, P. Salvador, J.J. Dannenberg, S. Dapprich, A.D. Daniels, O. Farkas, J.B. Foresman, J.V. Ortiz, J. Cioslowski, D.J. Fox, GAUSSIAN 09 (Revision B.01) (Gaussian Inc., Wallingford, 2010) 